\title{
ENDIS 4.0 as replay on requirements of Industry 4.0 in field of power supply and automation for mining
}

\begin{abstract}
This article presents a new product line for energy distribution and control ENDIS 4.0 from the perspective of the Industry 4.0 require-ments implemented by Europe. The paper presents various variants of the technical solution and possibilities of configuration and quick reconfiguration. The authors also included their remarks and observations of the current level of implementation of the Industry 4.0 guide-lines in the Polish as well as world mining industries.
\end{abstract}

Key words: ENDIS, Industry 4.0, Compact station, Energy distribution, transformation station, IoT

\section{INTRODUCTION}

The idea of Industry 4.0 is well-established in Europe. In Poland, the mining industry is increasingly being discussed and visible in the activities of many companies. The concept itself brings to mind the associations like an intelligent mine, plant, factory, digitalization, full integration of products with the infrastructure, and their communication with the manufacture or analysis of data in real time.

So, what is Industry 4.0? This is the fourth phase of the industrial (r)evolution. The first revolution took place in the 18th century and was based on the mechanization of production by using a steam engine. The second one started at the beginning of the 20th century after the introduction of mass production and use of electrification. The third one started after the popularization of automation in the 1970s, which was made possible by the dynamic development of electronics and IT solutions. The fourth revolution is happening now; this is a revolution based on cyber-physical systems and dynamic data processing (Fig. 1).

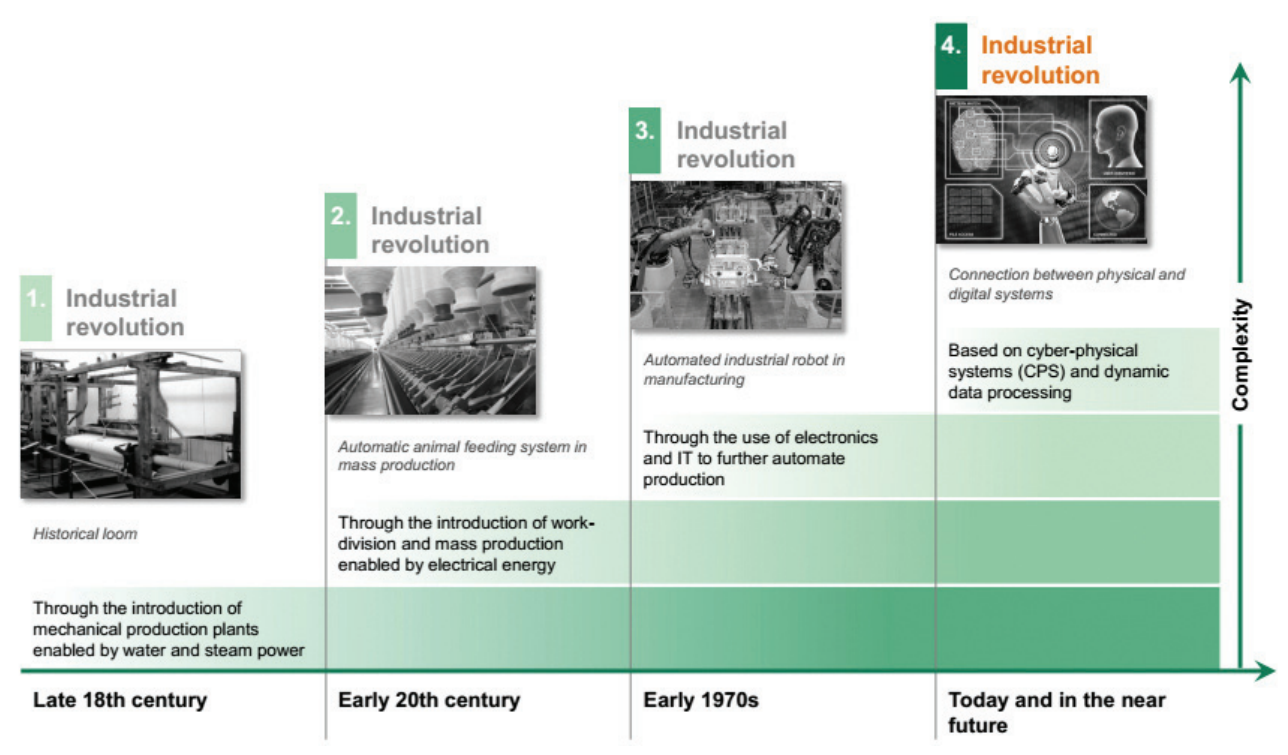

Fig. 1. Industrial revolution stages [1] 
As a world leader in the production of highly advanced electrical solutions for the mining industry, the Becker Group also meets the requirements of the Industry 4.0 as well as those of customers from all continents within its new ENDIS 4.0 product line. Below, we present the various technical and technological solutions in this area.

\section{ENDIS 4.0 - INTRODUCTION OF PRODUCT LINE REFFERRING TO INDUSTRY 4.0 REQUIREMENTS}

ENDIS 4.0 is a family of universal compact stations for different voltage levels depending on demand. Thanks to its modular construction, it provides the possibility for $4,8,12,16$, or 24 contactor panels (including circuit breakers). The compact station design enables use for voltages from $500 \mathrm{~V}$ to $4.16 \mathrm{kV}$, resistance to voltages up to $25 \mathrm{kV}$, a nominal current of $1250 \mathrm{~A}$, and a connecting short-circuit current of $25 \mathrm{kA}$. This feature makes it easy and quick to reconfigure stations due to customer requirements needs or configuration change of powered machines and equipment.

The compact station can be installed in the socalled high $(H)$ and low $(L)$ housing (Fig. 2). In the high version, 2 levels are available with up to 24 slots for contactor panels. The individual compartments are closed by a quick-action door. The construction enables its installation on the flange of the transformer station. The applied constructions are as standardized as possible and well-thought-out in terms of quick reconfiguration and servicing.

Additionally, housings can be equipped with many types of fast connectors and grooves on both sides (which is presented in Figure 3).

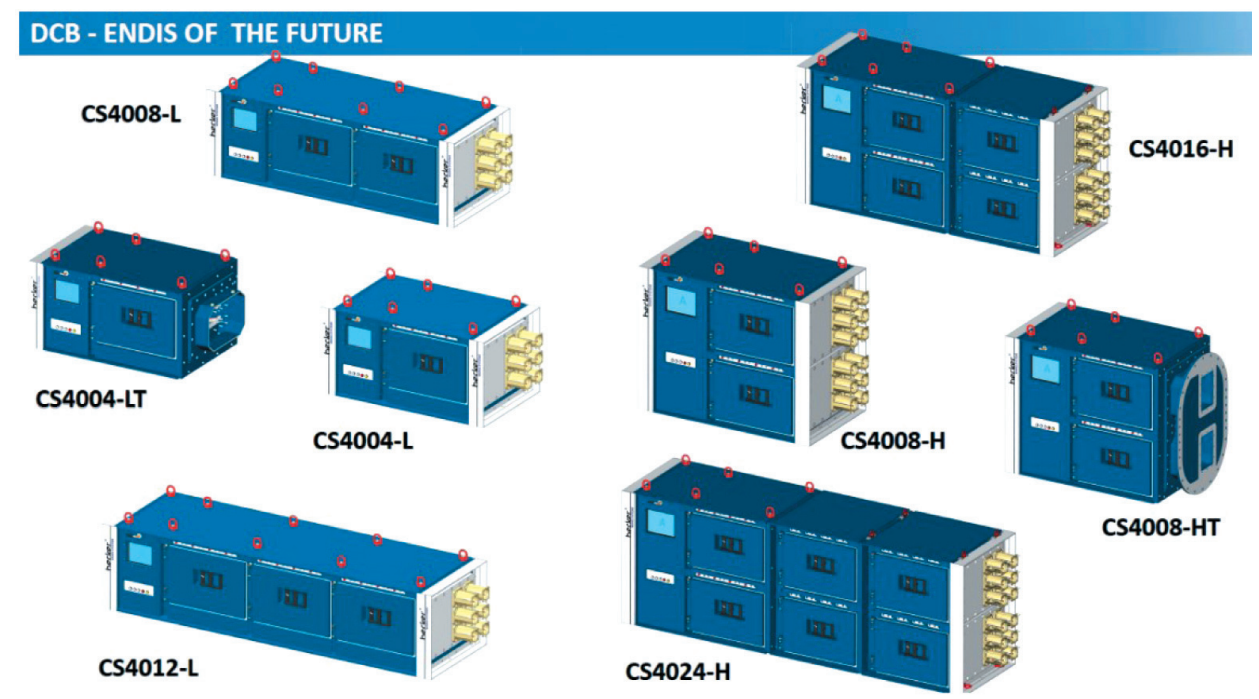

Fig. 2. Configuration possibilities of compact stations
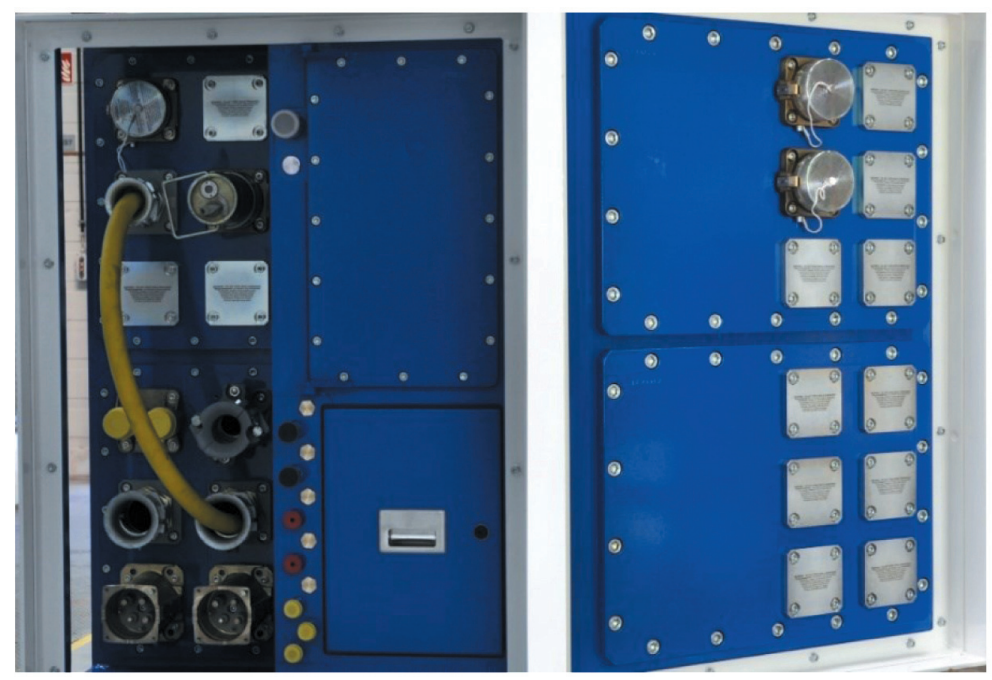

Fig. 3. Different types of connectors and grooves can be used 
The construction frame for the insertion of contactor panels (Fig. 4) is mounted completely outside the flameproof housing. The frame design eliminates the need to connect main and auxiliary bushes in a flameproof housing. Thanks to this, it is also possible to use a construction frame for inserting contactor panels in a non-explosive zone after installation in a suitable industrial enclosure. In addition, when there is a need to replace the interior of the casing in underground conditions, the entire structure can be prepared in a suitable place (workshop), and the whole structure can be changed at the station workplace.

Particular characteristics of the frame are as follows:

- contactor panels are electrically inserted and pulled out with the possibility of manual manipulation,

- automatic disconnection of faulty contactor panels from the main circuit with constant diagnostic connection to the panel,

- automatic recognition of inserted panel (no panel encoding);

- load capacity of main contacts up to $1000 \mathrm{~A}$,

- possibility of using a power switch up to $1000 \mathrm{~A}$,
- optionally integrated arc protection (optional),

- free-access at the back of the compact station for cable connections,

- universal sliding position for single and doubleand double-outlet contactor panels and transformer panels.

Compact stations of the ENDIS 4.0 family are equipped with the optimized new generation of contactor panels. The design of all of the contactor panels is identical for all voltage levels. The TCU 2-output contactor panels are made for rated voltages of up to $1140 \mathrm{~V}$ and load currents of $2 \times 250 \mathrm{~A}$, and they have a switching capacity of $4 \mathrm{kA}$. Contactor panel type HPC 500 has been designed for rated voltages of up to $4.16 \mathrm{kV}$, a $500 \mathrm{~A}$ load current, and a rated switching current of $6 \mathrm{kA}$. The power current contacts can be replaced independently. The CB 1000-type power switch has been designed for a rated voltage of $4.16 \mathrm{kV}$, rated current of $1000 \mathrm{~A}$, and holding capacity of $25 \mathrm{kA}$ (Fig. 5). The light output is integrated into the compact station without having to use the space for the contactor panel.
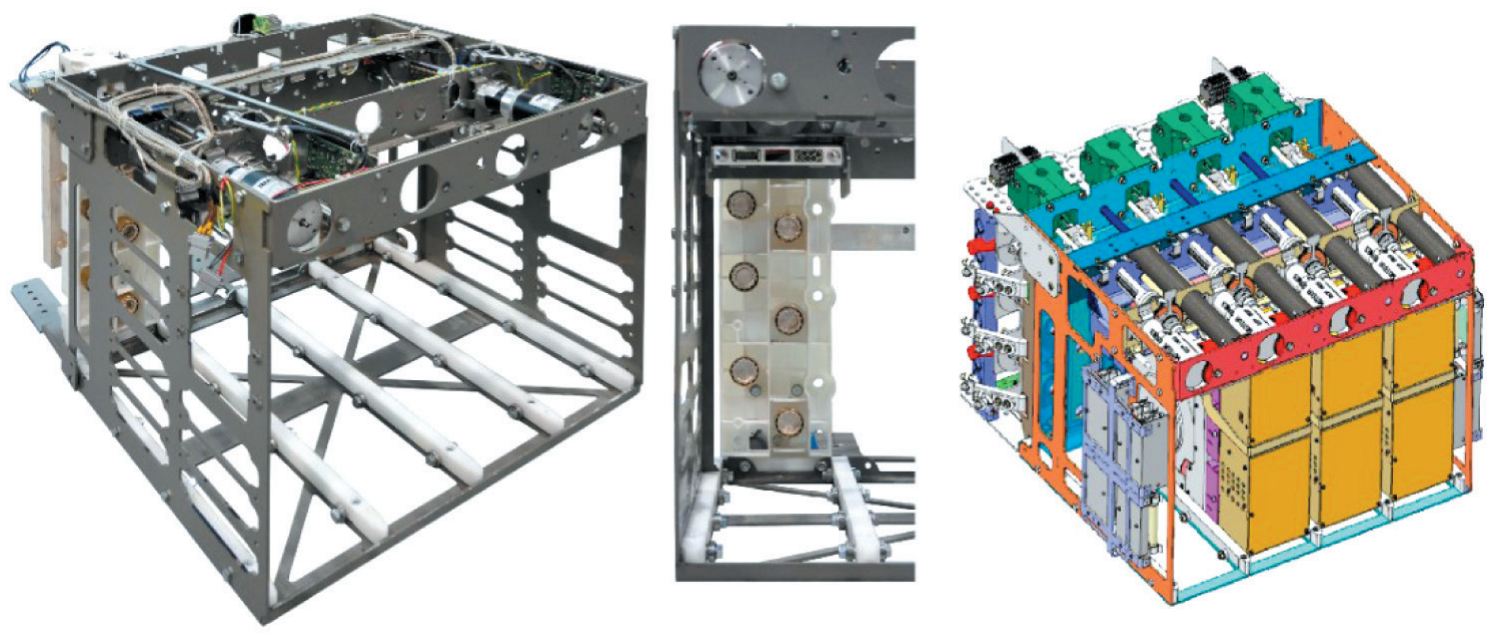

Fig. 4. Construction frame for insertion of contactor panels

CB 1000

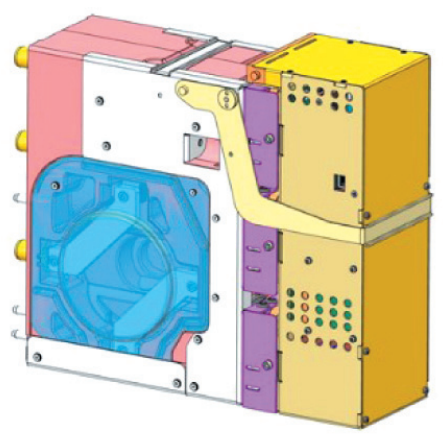

HPC 500

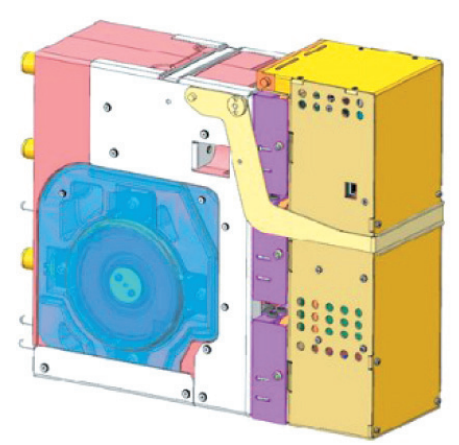

Fig. 5. Contactor panel 


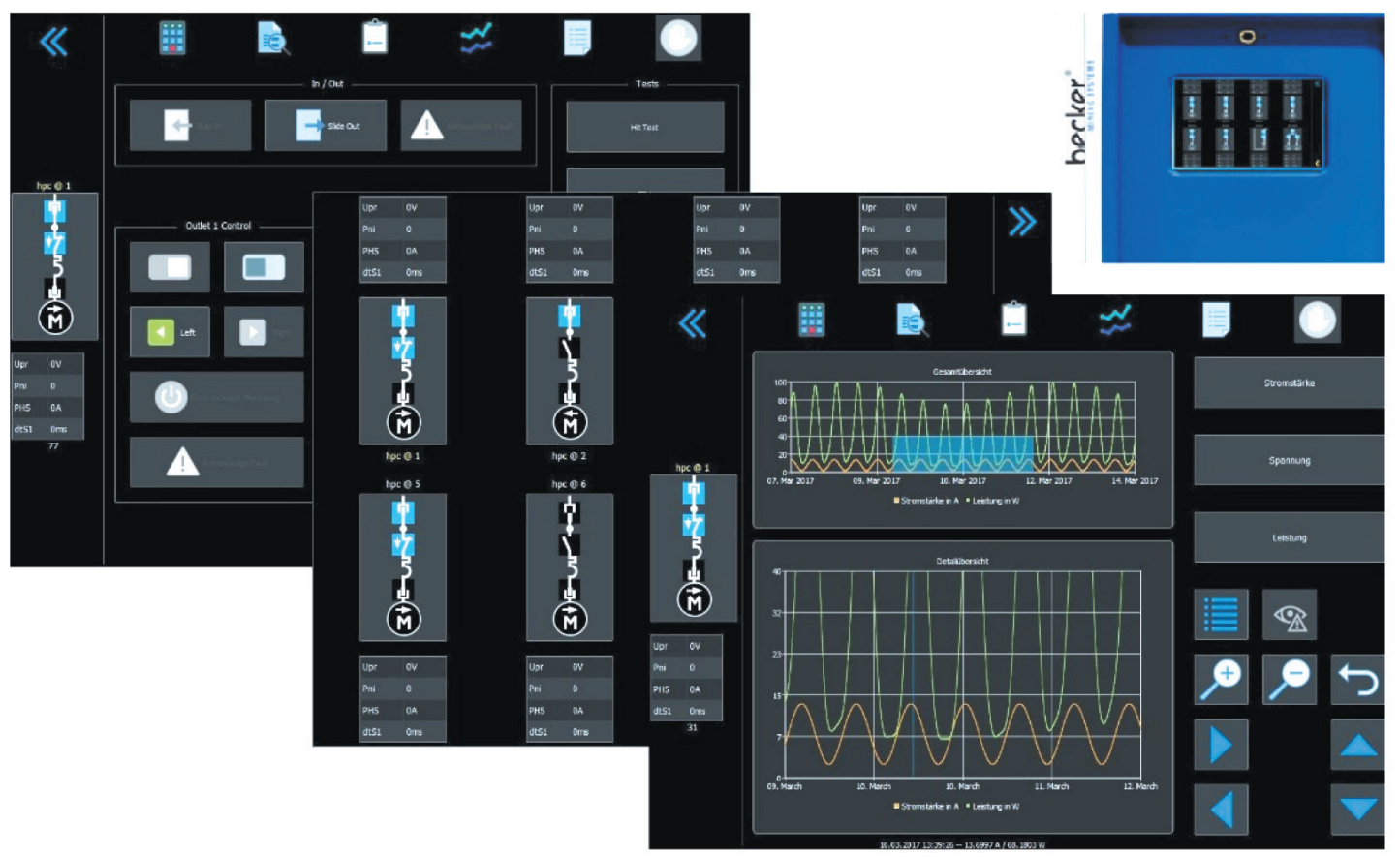

Fig. 6. Touch-screen display of compact station visualization panel - examples

The standard equipment is a control module with a transmission speed of $500 \mathrm{kBit} / \mathrm{s}$ for network interfaces and communication with contactor panels. The station has a 15-inch touch screen with full visualization of the diagnosis of individual panels, their configuration, and their history (Fig. 6). Even when the panel is disconnected from the main power supply, full diagnostic transmission and power supply of the control circuits is maintained.

At present, only a part of the equipment and sensors are connected together in industrial plants. Sensors combined with automation systems are mainly used to read parameters and control the production process. The Industrial Internet of Things means that more and more devices are equipped with built-in sensors and processors, which allows for efficient communication and interaction. It also influences the increasingly centralized control, and the decentralized analysts enable decisions to be made in the real world [1].

Within the compact station, all important components are diagnosable, "connected" and intelligent, and able to communicate with the outside world. Thanks to this feature, Becker's service team can even remotely determine which component has failed and how it happened. Additionally, thanks to such extensive diagnostics, it is possible in some cases to perform predictive service activities. The Becker Group places a particular emphasis on this functionality because of the fact that it has customers on every continent (where the possibility of remote service and prediction of failures amounts to significant savings in maintenance costs).

Optionally, the compact station can be integrated with the PLC via the Mincos AST, BTS, or other system bus interfaces (or others from customer requirements for applications without additional external controllers).

With widespread connectivity and the use of standard communication protocols from Industry 4.0, there is a growing need for cyber-attack protection or interference with the proper operation. As a consequence, the core of its cyber-security is the reliable communication and advanced user-identification systems providing access to the devices. ENDIS 4.0 fully meets these standards by protecting the communication interfaces as well as providing access to parameter changes or important settings.

For easy operation, commissioning, and servicing of the station via the 15 -inch screen, there are numerous easy-to-understand instructions available in both the text and graphic forms (schemes, animations) in the language of the user's country and other required languages. Additionally, the station can act as a transmission hub and converter between different transmission technologies (Fig. 7).

Additionally, Becker makes it possible to remotely connect to the compact station and remote support of customer service while allowing for such a connection. 

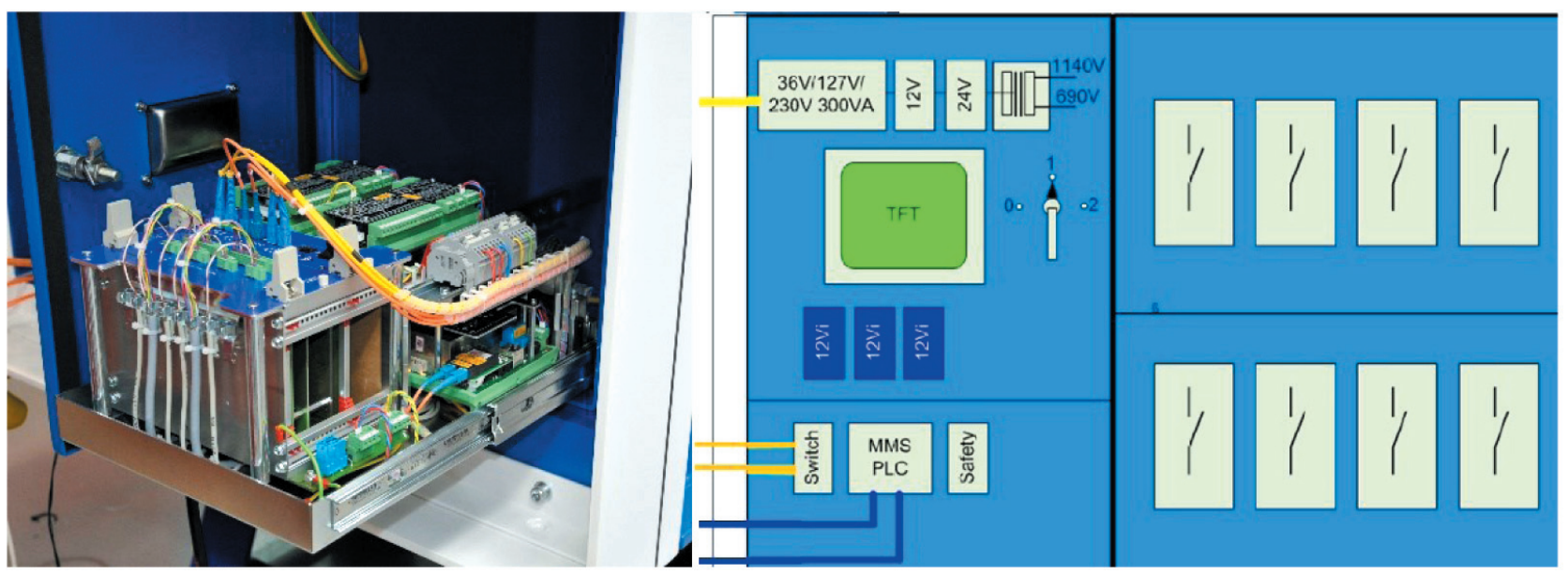

Fig. 7. Fully configurable transmission and control equipment [2]

The ENDIS 4.0 technology is fully integrated with the PROMOS 4.0 automation system and is integrated at both the hardware and software levels. The following figure shows the traditional configuration of the previous version of ENDIS and PROMOS on the left. Here, we can see a separate compact station for supplying the main motor of the belt conveyor, a stand-alone lighting module, and a Promos sys- tem controller. On the right, everything is integrated into the frames of the compact station thanks to the full integration of the ENDIS 4.0 into PROMOS 4.0.

The possibilities and functionality of the PROMOS 4.0 system are described in the article "Automation system of conveyors Promos 4.0" in the papers of the 13th International Conference on "Work safety of transport devices in mining" in 2017 [3].
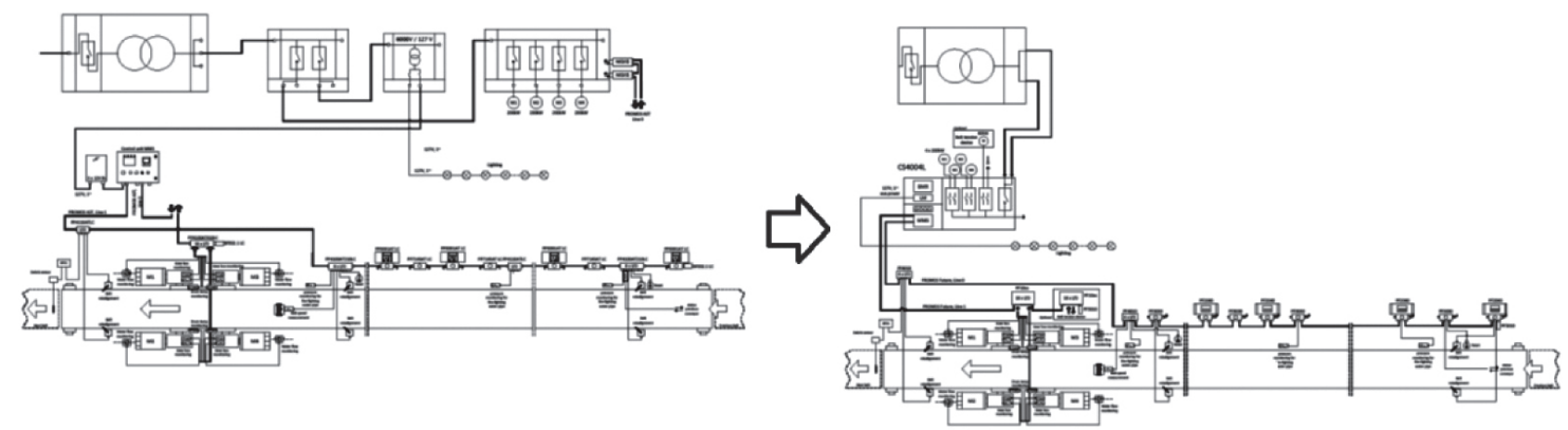

Fig. 8. Difference between traditional version of ENDIS \& PROMOS integration and version 4.0 of both products

\section{SUMMARY}

The world's mining industry is already moving on from Industry 3.0 to Industry 4.0. The results are already visible in the control of production, shortening of the investment preparation cycle, and customer relationships. Maintaining contact with international clients at the technical level with the world's top tycoons is an essential factor influencing the increase in the profitability of extraction.

One thing we should not forget about the regulatory issues related to the access to data (among other things). Companies collect huge amounts of data and are responsible for protecting it. The scale of technological changes accelerates exponentially. No one used smartphones ten years ago, and now we have such devices available even in potentially explosive atmospheres. It is likely that the longwall will be fully autonomous in ten years' time. We are unable to predict which new solutions will be available and what we will need in the future in our industry.

It is very important to overcome one of the main barriers to the effective implementation of Industry 4.0: the low awareness of staff and regulators. 
This is still a very fresh topic. The increasing use of automation systems, sensors, software, and analytical tools allows us to analyze the effects of the implemented solutions and (most importantly) focus on those changes that bring the greatest value.

A very important issue is also our education system, which should be based on projects and engineer knowledge how to solve a problem. We have plenty of talented engineers who crave for knowledge, but we lack the interdisciplinary specialists who combine the technical knowledge with business soft skills. That ones are needed to be able to fully implement the assumptions of the Industry 4.0 ideas.

The presented product group (ENDIS 4.0) is one of the components for reaching the Industry 4.0 level; however, whether and how we will use it depends only on ourselves.

\section{References}

[1] Boston Consulting: Industry 4.0 EN Opportunity or threat to the development of an innovative economy?, Becker Warkop's internal materials [unpublished].

[2] Instructions for use of Becker CS4008 stations.

[3] Szymiczek K., Lubryka J.: System automatyzacji przenośników typu Promos 4, in: Bezpieczeństwo pracy urządzeń transportowych w górnictwie: monografia, Centrum Badań i Dozoru Górnictwa Podziemnego, Lędziny 2018.

LESZEK ŻYREK, Eng. WOJCIECH ZASADNI, Ph.D., Eng. JAN LUBRYKA, M.Sc., Eng. RAFAE SZOETYSIK, M.Sc., Eng. Becker-Warkop Sp. z o.o. ul. Przemystowa 11, 44-266 Świerklany, Poland \{l.zyrek, w.zasadni, j.lubryka, r.szoltysik\} @becker-mining.com.pl 


\title{
ENDIS 4.0 jako odpowiedź na wymagania Przemysłu 4.0 w obszarze zasilania i sterowania dla górnictwa
}

\begin{abstract}
$W$ artykule przedstawiono nowa linie produktowa do rozdziatu energii i sterowania ENDIS 4.0 z perspektywy wymagań Przemyst 4.0 stawianych przed Europa. $W$ referacie zostaty zaprezentowane różnorodne warianty technicznego rozwiąania oraz możliwości konfiguracji i szybkiej rekonfiguracji. Autorzy zawarli również swoje przemyślenia oraz obserwacje aktualnego stopnia wdrożenia wytycznych Przemystu 4.0 w polskiej i światowej branży górniczej.
\end{abstract}

Słowa kluczowe: ENDIS, przemyst 4.0, stacja kompaktowa, przesyła energii, stacja transformatorowa, IoT

\section{WSTĘP}

Idea Przemysłu 4.0 już na dobre zakorzeniła się w Europie. W Polsce w branży górniczej jest coraz częściej omawiana i widoczna w działaniach wielu firm. Samo pojęcie przywołuje na myśl skojarzenia związane z inteligentną kopalnią, zakładem, fabryką, digitalizacją, pełną integracją produktów z infrastrukturą, ich komunikacją z producentem czy analizą danych w czasie rzeczywistym.

Czym w takim razie jest Przemysł 4.0? To czwarty etap (r)ewolucji przemysłowej. Pierwsza rewolucja miała miejsce w XVIII wieku i oparta była na mechanizacji produkcji dzięki wykorzystaniu maszyny parowej. Druga z kolei rozpoczęła się na początku wieku XX po wprowadzeniu produkcji masowej i wykorzystaniu elektryfikacji. Trzecia rozpoczęła się po upowszechnieniu automatyzacji w latach siedemdziesiątych ubiegłego wieku, co było możliwe dzięki dynamicznemu rozwojowi elektroniki i rozwiązań IT. Czwarta rewolucja toczy się obecnie. To rewolucja oparta na systemach cyberfizycznych i dynamicznym przetwarzaniu danych (rys. 1).

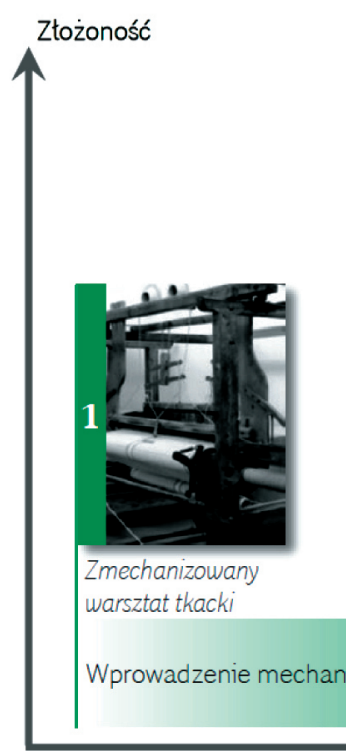

Późny wiek XVIII

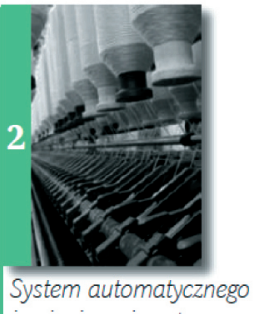
zywienia zwierzq̨

Wprowadzenie podziatu pracy i masowej produkcji dzięki energii elektrycznej
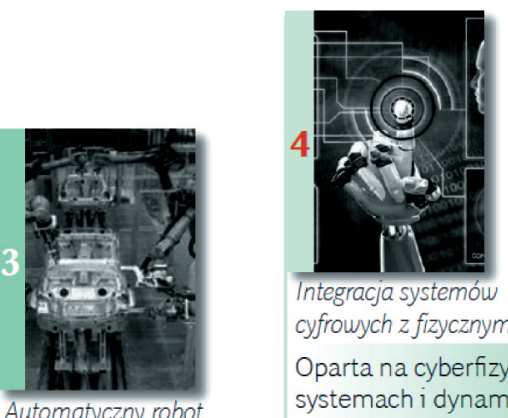

cyfrowych $z$ fizycznym

Oparta na cyberfizycznych systemach i dynamicznym przetwarzaniu danych

Użycie elektroniki i rozwiązań IT dla dalszej automatyzacji produkcji

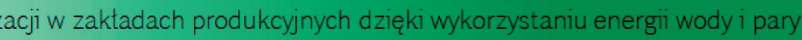

Wczesny wiek XX

Wczesne lata '70

Dziś i w niedalekiej przysztości

Rys. 1. Etapy rewolucji przemystowej [1] 
Grupa Becker jako światowy lider w produkcji wysoko zaawansowanych rozwiązań elektrotechnicznych dla przemysłu górniczego w ramach nowej linii produktowej ENDIS 4.0 również spełnia wymagania Przemysłu 4.0, a także wymagania klientów ze wszystkich kontynentów. Poniżej przedstawiamy poszczególne rozwiązania techniczne i technologiczne w tym obszarze.

\section{ENDIS 4.0 - \\ PRZEDSTAWIENIE LINII PRODUKTOWEJ W STOSUNKU DO WYMAGAŃ PRZEMYSŁU 4.0}

ENDIS 4.0 to rodzina uniwersalnych stacji kompaktowych przeznaczonych dla różnych poziomów napięcia, w zależności od zapotrzebowania. Dzięki konstrukcji modułowej przewiduje zabudowę 4, 8, 12, 16 lub 24 paneli stycznikowych, w tym również wyłącz- nikowych. Konstrukcja stacji kompaktowej umożliwia stosowanie dla napięć od $500 \mathrm{~V}$ do $4,16 \mathrm{kV}$, posiada odporność na napięcia do $25 \mathrm{kV}$, prąd znamionowy $1250 \mathrm{~A}$ oraz łączeniowy prąd zwarcia $25 \mathrm{kA}$. Ta cecha umożliwia łatwą i szybką rekonfigurację stacji w miarę zmieniających się wymagań klienta czy zasilanych maszyn i urządzeń.

Stacja kompaktowa może wystąpić w obudowie (rys. 2) tzw. wysokiej $(H)$ i niskiej $(L)$. W wersji wysokiej dostępne są dwa poziomy z maksymalnie 24 miejscami dla paneli stycznikowych. Poszczególne przedziały są zamknięte drzwiami z systemem szybkiego otwierania. Konstrukcja umożliwia jej zabudowę na kołnierzu stacji transformatorowej. Zastosowane konstrukcje są maksymalnie ustandaryzowane oraz przemyślane pod względem szybkiej rekonfiguracji oraz serwisowania.

Dodatkowo obudowy mogą być wyposażone w różnego rodzaju szybkozłącza oraz wpusty po obydwu stronach, co zostało przedstawione na rysunku 3.

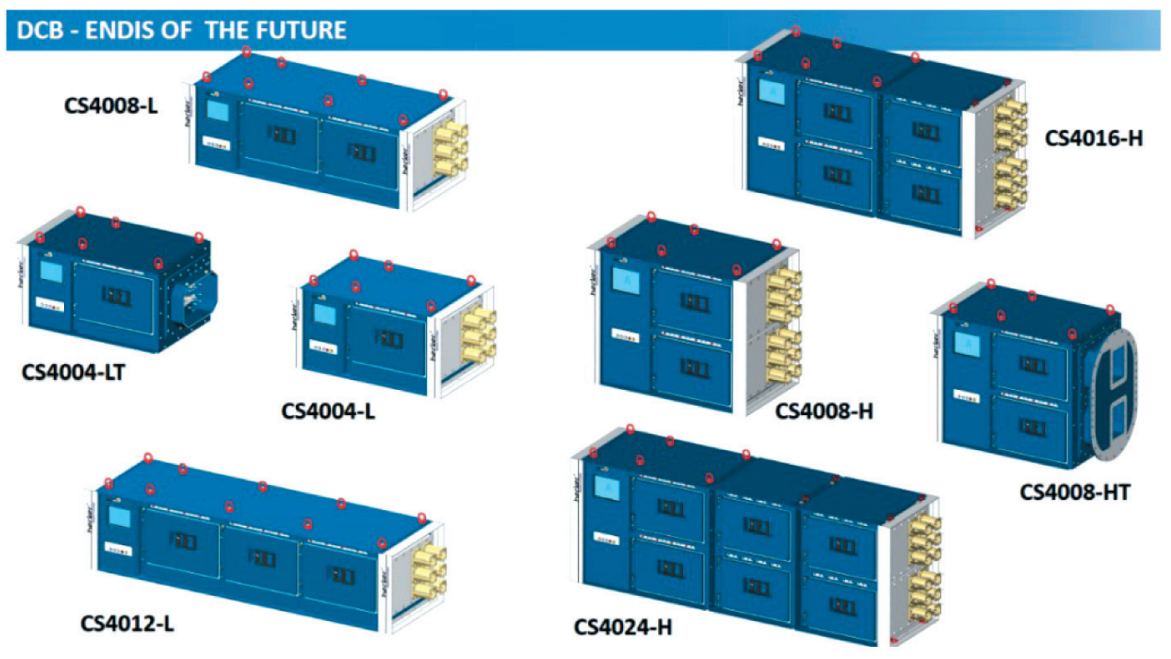

Rys. 2. Możliwości konfiguracji stacji kompaktowych
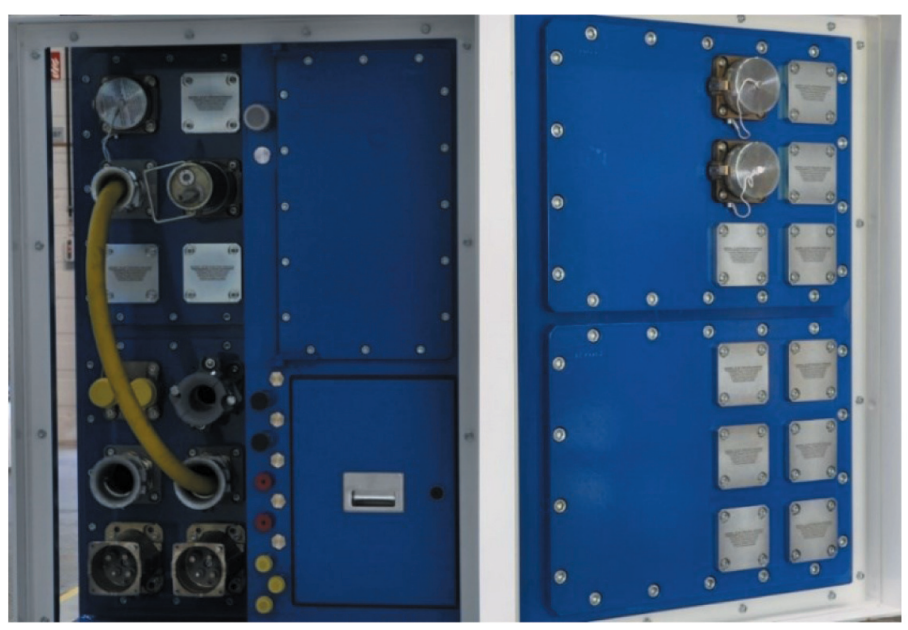

Rys. 3. Możliwość zastosowania różnego rodzaju złaczy oraz wpustów 
Rama konstrukcyjna (rys. 4) dla paneli stycznikowych montowana jest całkowicie poza obudową ognioszczelną. Konstrukcja ramy eliminuje konieczność łączenia obwodów głównych i pomocniczych w obudowie ognioszczelnej. Dzięki temu możliwe jest także zastosowanie ramy konstrukcyjnej dla paneli stycznikowych w strefie niezagrożonej wybuchem, a następnie jej zabudowę $\mathrm{w}$ odpowiedniej osłonie przemysłowej. Dodatkowo w przypadku potrzeby wymiany wnętrza obudowy w warunkach dołowych, cała konstrukcja jest przygotowywana w miejscu do tego sprzyjającym (warsztat), a w miejscu pracy stacji dokonywana jest podmiana całej konstrukcji.

Szczególne właściwości ramy konstrukcyjnej:

- panele stycznikowe są podłączane i odłączane od obwodów silnoprądowych elektrycznie z możliwością manualnej ingerencji,

- automatyczne odłączanie uszkodzonych paneli stycznikowych od obwodu silnoprądowego, z zachowaniem połączeń diagnostycznych i zasilania sterowniczego,

- automatyczne rozpoznawanie podłączanych paneli (brak kodowania),

- obciążalność styków głównych do 1000 A,

- możliwość zastosowania wyłącznika mocy do 1000 A,
- zintegrowane opcjonalnie zabezpieczenie łukochronne,

- swobodny dostęp do tylnej części stacji kompaktowej w celu podłączenia przewodów,

- uniwersalne miejsce przeznaczone do podłączenia paneli stycznikowych jedno- i dwuodpływowych oraz transformatorowych.

Stacje kompaktowe z rodziny ENDIS 4.0 wyposażane są w zoptymalizowaną nową generację paneli stycznikowych. Konstrukcja wszystkich paneli stycznikowych jest identyczna dla wszystkich poziomów napięcia. Dwuodplywowe panele stycznikowe TCU zostały wykonane dla napięcia znamionowego wynoszącego do $1140 \mathrm{~V}$, prądów obciążenia $2 \times 250$ A i posiadają zdolność łączeniową wynoszącą 4 kA. Panel stycznikowy typu HPC 500 został wykonany dla napięć znamionowych do $4,16 \mathrm{kV}$, prądu obciążenia 500 A oraz prądu znamionowego łączeniowego wynoszącego $6 \mathrm{kA}$. Styki silnoprądowe można wymieniać samodzielnie. Wyłącznik mocy typu CB 1000 został wykonany dla napięcia znamionowego wynoszącego $4,16 \mathrm{kV}$, prądu znamionowego wynoszącego $1000 \mathrm{~A}$ i posiada zdolność łączeniową wynoszącą $25 \mathrm{kA}$ (rys. 5). W stacji kompaktowej zintegrowano wyjście oświetleniowe bez potrzeby wykorzystania miejsca podłączania dla panelu stycznikowego.
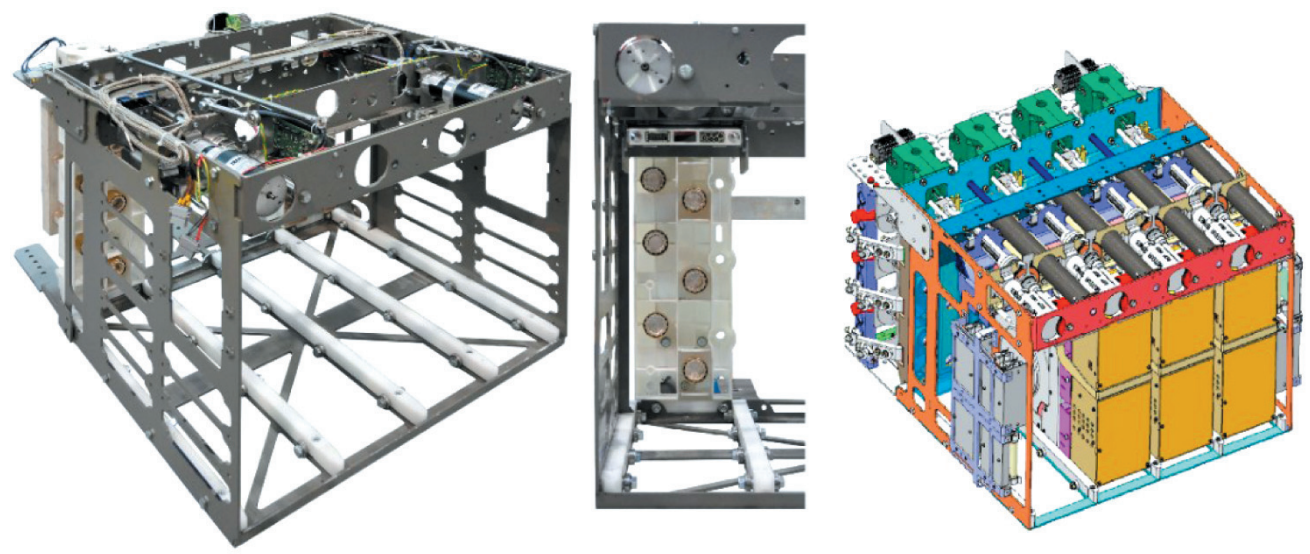

Rys. 4. Rama konstrukcyjna dla paneli

CB 1000

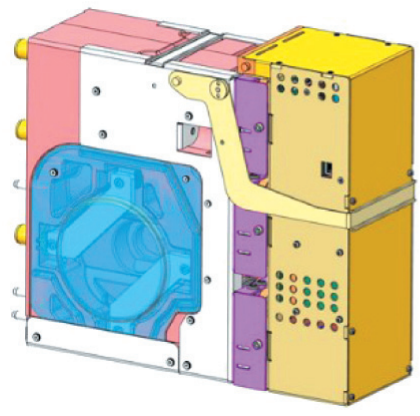

HPC 500

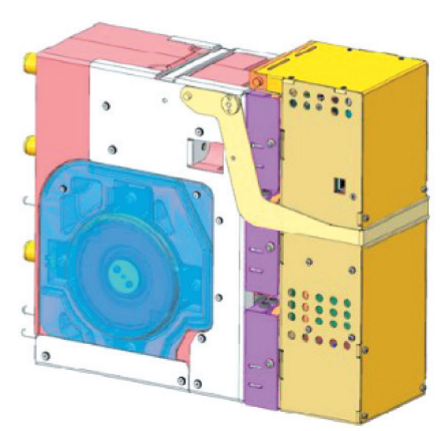

Rys. 5. Panele stycznikowe 


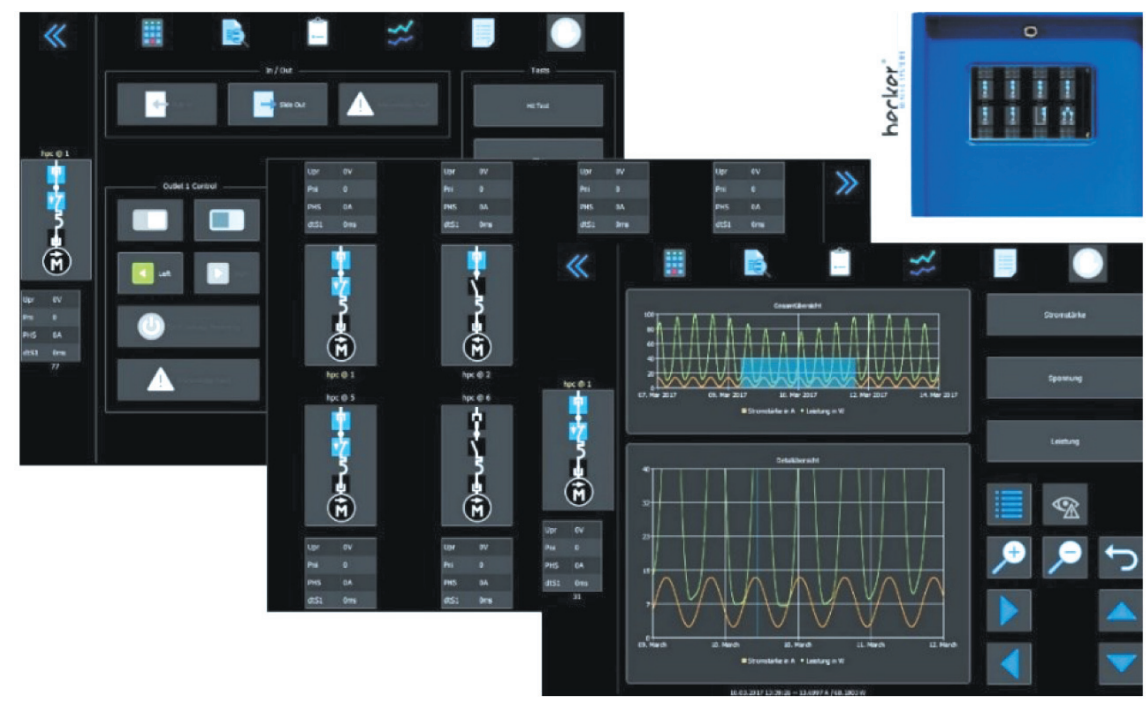

Rys. 6. Ekran panelu dotykowego do wizualizacji stacji kompaktowej - przykłady

Wyposażeniem standardowym jest moduł kontrolny o prędkości transmisji wynoszącej $500 \mathrm{kBit} / \mathrm{s}$ dla interfejsów sieciowych oraz komunikacji z panelami stycznikowymi. Stacja posiada 15-calowy ekran dotykowy z pełną wizualizacją diagnostyki poszczególnych paneli, ich konfiguracji oraz historii ich pracy (rys. 6). Nawet przy wysuniętym panelu zachowana jest pełna transmisja diagnostyczna i zasilanie obwodów sterowniczych.

Obecnie w zakładach przemysłowych tylko część urządzeń i sensorów jest ze sobą połączona. Sensory połączone z systemami automatyki służą głównie do odczytywania parametrów i sterowania procesem produkcyjnym. Przemysłowy Internet Rzeczy sprawia, że coraz więcej urządzeń ma wbudowane czujniki i procesory, co pozwala na ich sprawną komunikację i interakcję. Wpływa to również na coraz bardziej scentralizowaną kontrolę, a zdecentralizowana analityka umożliwia podejmowanie decyzji w czasie rzeczywistym [1].

W ramach stacji kompaktowej wszystkie istotne podzespoły są diagnozowalne, „usieciowione” $\mathrm{i}$ inteligentne, przez co potrafią komunikować się ze światem zewnętrznym. Dzięki tej funkcjonalności nawet zdalnie serwis firmy Becker jest w stanie bardzo precyzyjnie stwierdzić, który z podzespołów uległ awarii i w jaki sposób do niej doszło. Dodatkowo dzięki szerokiej diagnostyce w niektórych przypadkach istnieje możliwość predyktywnych działań serwisowych. Grupa Becker kładzie na tę funkcjonalność szczególny nacisk z uwagi na to, że ma klientów na całym świecie, a więc możliwość zdalnego serwisu i przewi- dywania awarii jest znaczną oszczędnością kosztów serwisowych.

Opcjonalnie stacja kompaktowa może być zintegrowana $\mathrm{z}$ sterownikiem PLC przez interfejsy magistrali systemowej Mincos AST, BTS lub innym wymaganym przez klienta w celu wykonywania aplikacji bez stosowania dodatkowych sterowników zewnętrznych.

Wraz z upowszechniającą się łącznością i wykorzystaniem standardowych protokołów komunikacyjnych wywodzących się z Przemysłu 4.0 rośnie potrzeba stosowania zabezpieczeń przed cyberatakami lub zakłóceniem poprawnego działania. W konsekwencji istotą cyberbezpieczeństwa jest niezawodna komunikacja i zaawansowane systemy identyfikacji użytkowników udzielające dostępu do urządzeń. ENDIS 4.0 w pełni spełnia te standardy dzięki zabezpieczeniu interfejsów komunikacyjnych i wprowadzeniu poziomów dostępu do zmian parametrów czy istotnych ustawień i funkcji.

W celu ułatwienia obsługi, uruchamiania i serwisowania stacji za pośrednictwem 15-calowego panelu dotykowego dostępne są liczne, zrozumiałe instrukcje $\mathrm{w}$ formie tekstowej oraz graficznej (schematy, animacje) w języku kraju użytkownika oraz innych wymaganych językach. Dodatkowo stacja może pełnić funkcję centrali transmisyjnej oraz konwertera pomiędzy różnymi technologiami transmisji (rys. 7).

Dodatkowo istnieje możliwość zdalnego podłączenia się serwisu do stacji kompaktowej i zdalnego wsparcia obsługi u klienta przy umożliwieniu takiego połączenia $\mathrm{w}$ infrastrukturze użytkownika. 

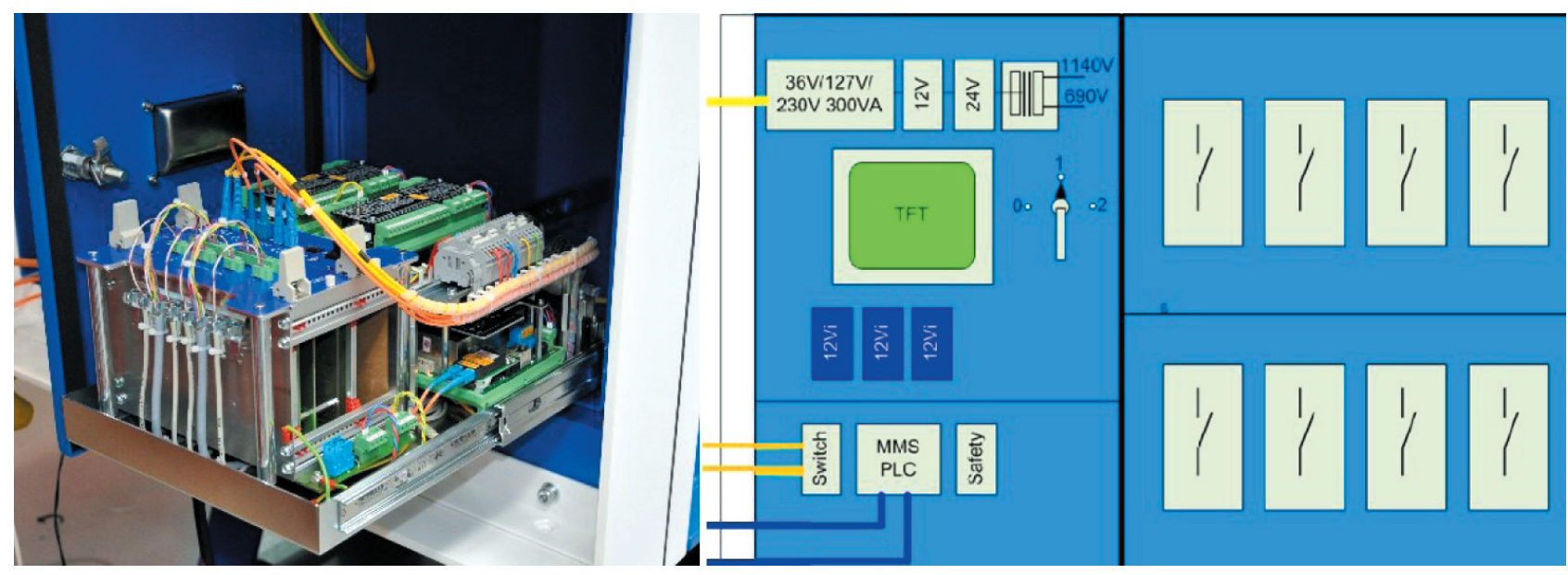

Rys. 7. W petni konfigurowalne wyposażenie transmisyjno-sterownicze [2]

Technologia ENDIS 4.0 jest w pełni zintegrowana z systemem automatyki PROMOS 4.0 (rys. 8). Integracja odbywa się zarówno na poziomie sprzętowym, jak i poziomie oprogramowania. Na rysunku 8 przedstawiono tradycyjną konfigurację wcześniejszej wersji systemu ENDIS i PROMOS. W lewej części rysun- ku widać oddzielną stację kompaktową do zasilania głównych odpływów przenośnika taśmowego, oddzielny moduł oświetleniowy oraz sterownik systemu PROMOS. Po prawej stronie dzięki pełnej integracji ENDIS $4.0 \mathrm{z}$ systemem PROMOS 4.0 wszystko jest zintegrowane $w$ ramach jednej stacji.
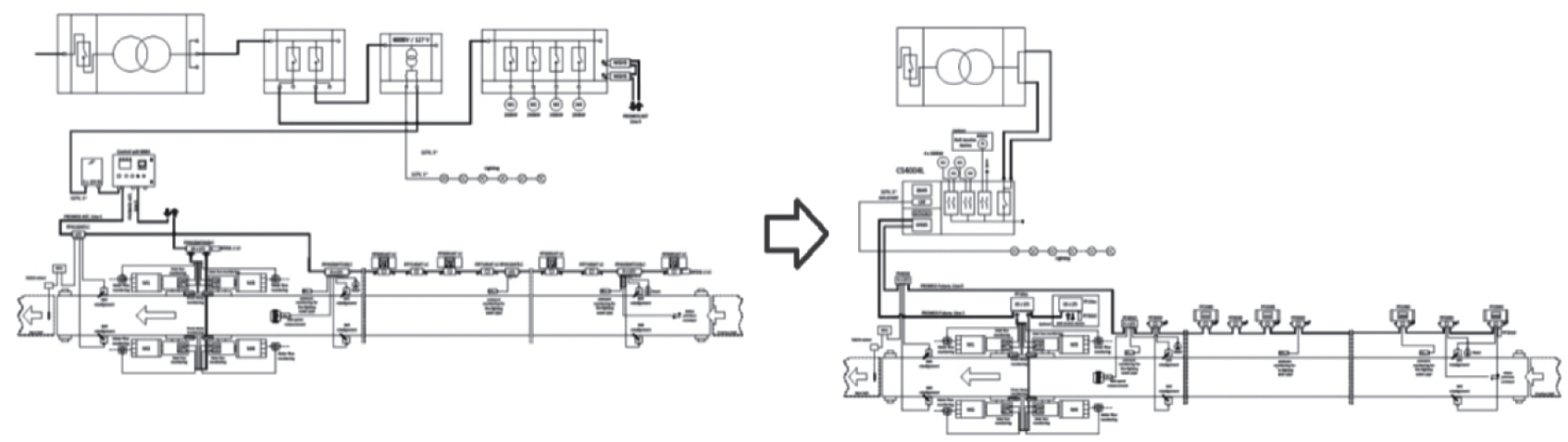

Rys. 8. Różnica pomiędzy tradycyjna integracją ENDIS i PROMOS oraz nowa 4.0 obu linii produktowych

Możliwości i funkcjonalność systemu PROMOS 4.0 zostały opisane w artykule System automatyzacji przenośników typu Promos 4.0 zaprezentowanym na XIII Międzynarodowej Konferencji „Bezpieczeństwo pracy urządzeń transportowych w górnictwie" w 2017 roku [3].

\section{PODSUMOWANIE}

Światowa branża górnicza przechodzi z Przemysłu 3.0 do 4.0, czego rezultaty widać w sterowaniu produkcją, skracaniu cyklu przygotowania inwestycji czy relacjach z klientem. Utrzymanie kontaktu m.in. na poziomie technicznym ze światowymi poten- tatami górniczymi jest niezbędnym czynnikiem mającym wpływ na wzrost opłacalności wydobycia.

Nie można zapomnieć o kwestiach regulacyjnych związanych m.in. z dostępem do danych. Firmy zbierają ogromną ilość danych i ponoszą odpowiedzialność za to, by je chronić. Skala zmian technologicznych przyspiesza wykładniczo. Dziesięć lat temu nikt nie korzystał ze smartfonów, a teraz posiadamy takie urządzenia dostępne nawet $\mathrm{w}$ atmosferach zagrożonych wybuchem. Istnieje prawdopodobieństwo, iż za dziesięć lat kompleksy wydobywcze będą już w pełni autonomiczne. Nie jesteśmy w stanie przewidzieć, jakie nowe rozwiązania będą dostępne i czego będziemy potrzebować w przemyśle. 
Bardzo ważne jest pokonanie jednej z głównych barier efektywnego wdrożenia Przemysłu 4.0: niskiej świadomości kadr oraz organów regulacyjnych. Jest to wciąż świeży temat. Coraz większe wykorzystanie systemów automatyki, sensorów, oprogramowania i narzędzi analitycznych pozwala analizować efekty wdrożonych rozwiązań i co najważniejsze - koncentrować się na tych zmianach, które wnoszą największą wartość.

Bardzo istotną kwestią jest również nasz system edukacji, który powinien być oparty na projektach i uczyć inżynierów rozwiązywania problemów. Polska ma mnóstwo zdolnych i głodnych wiedzy inżynierów, ale brakuje specjalistów interdyscyplinarnych łączących wiedzę techniczną z biznesowymi umiejętnościami miękkimi. A właśnie takowe są wymagane, aby móc w pełni wdrażać założenia Przemysłu 4.0.

Zaprezentowana grupa produktowa ENDIS 4.0 jest jedną ze składowych, środkiem dojścia do pozio- mu Przemysłu 4.0, ale czy i jak ją wykorzystamy, to zależy tylko od nas samych.

\section{Literatura}

[1] Boston Consulting: Przemyst 4.0 PL Szansa czy zagrożenie dla rozwoju innowacyjnej gospodarki?, opracowanie wewnętrzne firmy Becker Warkop [niepublikowane].

[2] Instrukcja obsługi stacji CS4008 firmy Becker.

[3] Szymiczek K., Lubryka J.: System automatyzacji przenośników typu Promos 4, in: Bezpieczeństwo pracy urzadzeń transportowych w górnictwie: monografia, Centrum Badań i Dozoru Górnictwa Podziemnego, Lędziny 2018.

inż. LESZEK ŻYREK

dr inż. WOJCIECH ZASADNI

mgr inz. JAN LUBRYKA

mgr inz. RAFAE SZOETYSIK

Becker-Warkop Sp. z o.o.

ul. Przemystowa 11, 44-266 Świerklany

\{l.zyrek, w.zasadni, j.lubryka, r.szoltysik\}

@becker-mining.com.pl 